\title{
TREE APPRAISAL METHODS AND THEIR APPLICATION - FIRST RESULTS IN ONE OF BUDAPEST'S DISTRICTS
}

\author{
HEGEDÜS, A. ${ }^{1 *}$ - GAÁL, M. ${ }^{1}$ - BÉRCES, R. ${ }^{2}$ \\ ${ }^{I}$ Corvinus University of Budapest, Department of Mathematics and Informatics \\ 1118 Budapest Villányi út 29-43., Hungary \\ (phone: +36-1-482-6261; fax: +36-1-466-9273) \\ ${ }^{2}$ Budapest University of Technology and Economics, Department of Management and \\ Corporate Economics \\ 1117 Budapest, Magyar tudósok körútja 2., Hungary \\ (phone: +36-1-463-2782; fax: +36-1-463-1606) \\ *Corresponding author \\ e-mail:andras.hegedus@uni-corvinus.hu \\ (Received $21^{\text {st }}$ November 2011; accepted $2^{\text {nd }}$ December 2011)
}

\begin{abstract}
Street trees provide a number of environmental and social benefits, including contributing to climate change adaptation and mitigation and providing urban green space. In all settlements is important to know the quantity and quality of the trees and develop up-to-date tree cadastres. Frequently there is a need to place a monetary value on amenity trees, therefore several methods with different approaches have been developed. In our paper we discuss and compare some widely applied international and Hungarian methods taken into consideration their benefits and disadvantages. A tree survey was done in the year 2010, in one of the greenest districts of Budapest. Based on the survey species composition, distribution by age of the trees, condition of the trees, proportion of the fruit and ornamental trees were analysed and calculations were done regarding the tree values. Results show that good judgement through experience is important in selecting the method to use, for no one method can be used under every condition.
\end{abstract}

Keywords: tree appraisal, Budapest, tree value calculation, Radó method, Párkányi method

\section{Introduction}

Street trees should be considered as a part of a settlement's infrastructure, namely the "green infrastructure". Therefore tree cadastral assessments should be among the important and regularly performed activities in all settlements and cities. These surveys can give an adequate picture of the species, age, condition and the exact location of the trees in the public areas. All people expect to have a healthy living environment therefore a reasonable demand is for the professional maintenance of the green areas. The planning of the maintenance works (e.g., need of manpower to clean up of the falling crops, pruning to prevent accidents, determine the trees that may be removed) requires also the accurate knowledge of the trees. Tree cadastre has an important role in defining the commons (aesthetic value as well), on the other hand in determining the value of the - with or without permission - removed trees, calculating the extent of the caused damages.

During the surveys the precise mapping should be emphasised. The cadastral maps should be kept continuously up to date, i.e. all planting and cutting must be marked immediately, the state of the storm damaged trees should be updated to keep up to date information available. Besides respecting these basic updates a full survey should be needed every 5 years recording the changes during that time and controlling the 
intermediate updates. Experience, however, that most of the settlements do not carry out tree cadastral surveys, due too the lack of financial resources. When they do, the survey often does not extend beyond the data recording and some basic statistics.

Many times there is a need for using such methods that allows defining the values (whether expressed in monetary value) of the trees by standard criteria, so the trees become comparable. Amenity tree evaluation systems are widely used all around the world. They place a monetary value on trees, usually for the purposes of insurance, compensation and litigation. However, the major significance of placing such a value on trees is that they are then recognised as assets.

\section{Review of literature}

\section{Factors in the tree evaluation methods}

The terms valuation (or evaluation) and appraisal are frequently used interchangeably (Kielbaso, 1979; Watson, 2002; Cullen, 2007; Sarajevs, 2011), and that is the intent here. However, they may be distinguished in particular practice settings, as the term appraisal may describe non-monetary values (Litchfield, 2010).

Several tree evaluation methods were developed in the world, in Hungary some domestic methods are in use. Their particular uses vary with the size of tree, species, purpose, nature of loss, etc. Plant appraisal may involve more than just trees; it often includes shrubs, vines, ground plants and landscape structures (Dreesen, 2005).

All calculations have some kind of base value. In most cases this is the producer price of the given nursery. This can raise now some problems in itself, because no matter how old, how many times replaced and what size has the sapling considered for the basic value. Revised Burnley method uses a specific approach, as the base value is the cost per cubic meter of retail nursery stock (Moor, 1991).

Determining the base value it is advised using the average prices of several nurseries, because even within the country may be $200-300 \%$ price difference among the ornamental trees with the same size and other properties. Bulír (2009) made calculations for the base tree prices in the Czech Republic. His calculations indicate that prices of individual taxa may differ considerably. The differences are caused by the following factors: tree species (cultivar) itself, chosen young plant size, genetic qualities of the evaluated taxon - and above all, speed of maturation growth and crown size.

The calculation of the planted price is also common, which means the cost of planting and follow-up care (from planting to the beginning of the growing) of a given variety with a defined size at a certain place.

Choosing the sapling for planting must be considered that the tree can fulfil its function and reaches the value of the formerly removed tree as soon as possible. Therefore the replacement cost method is also commonly used. However, replace the same number and size of plants is usually used on small trees and shrubs. According to King (1977) for trees over 18 inches $(45 \mathrm{~cm})$ in diameter, this may be impractical. The other possibility is replacing a large tree with several small trees which may equal the total diameter of the large tree. Calculating the replacement cost, the tree size is a limiting factor. It is not possible to plant a tree of any size, not all of tree species have available elderly specimen and large plants are often unrealistically expensive. This is partly due to the additional costs and manning requirement, on the other hand a much smaller supply compared to the young plants results in a higher than realistic price. 
The base value should be corrected with different factors. Size, species, condition and location are the generally used appraisal factors.

There are different opinions about the consideration of the tree size and its quantification. Several methods use values of trunk circumferences, height or crown volume. In case of a given species these can be important factors, but in a tree survey, where several different species can be found, these can lead astray, since the species have very different growth types and vigour.

It is advised using the age (as well), because this can be a basis for comparison independently from the species. Age, as a characteristic of the size, is independent from the place of the planting and specific ecological conditions, is acceptable as an appreciation factor, and a frequently used argument is that the maintenance costs during the years can be included in the value of the tree. In this case the higher age means more cost and also a higher tree value.

Based on studies most of the environmental impacts of the trees are related to the canopy. Therefore, some methods are based on the size of canopy (Jószainé Párkányi, 2004). However, the canopy size is proportional to the age and during the surveys the determination of the age is easier.

Tree size can also be determined by the cross-sectional area of the trunk. According to Dreesen (2005) for trees with a diameter of 4 inches or smaller, the diameter should be determined at a height of 6 inches above the ground. For trees with a diameter of 5 to 8 inches, the diameter is determined 12 inches above the ground. For trees with diameters larger than 8 inches, the diameter is determined at a height of 4.5 feet. For multi-trunked trees, full diameter of the largest trunk plus half the diameter of the other trunks determines the diameter for computing the cross section area. Application of the trunk size is also desirable if trees are cut for timber use.

Tree species and cultivars vary widely in aesthetic, functional and maintenance characteristics and/or requirements. Species ratings are affected by adaptability to soil and climatic differences; growth characteristics; maintenance requirements; susceptibility to insects, diseases and air pollution; allergenic properties and aesthetic values (Kissinger and Van Ells, 1998). Species rating is usually expressed as a percentage relative to a ,high quality” specimen, and often varies geographically. The influence of species quality on appraised value varies with method (Watson, 2002). Grouping tree species into value classes is subjective and may vary also from one part of the state and one tree specialist to another.

Location can have different aspects in the appraisal. The design and quality of the surroundings is an important factor. For example, a tree in a well-maintained suburban residential area will rate very differently than that same tree in front of a factory. The aesthetic aspect usually means ,the right tree in the right place", but with the location factor we might even consider, a wrong tree in the right place” (Kielbaso, 1979). A plant's placement may determine its functional attributes, like providing summer shade, windbreak, erosion control, etc.

The condition of a tree depends on overall vigour, size, form, decay, insect and disease problems and expected life (Kielbaso, 1979). As trees become old they often become defective through decay, broken limbs, damage by humans or uneven growth. Only an experienced evaluator can make accurate condition determinations, as knowledge of tree pathology, entomology and physiology is important to do it. The specialist appraising the tree usually must judge the condition on a percentage basis. A tree that has a hazardous condition (cracks, weak branches) could even have a negative 
value if it is unsafe and should be removed. In this case there will be a cost for removal and cleanup (Kissinger and Van Ells, 1998). To the air quality improvement only trees with a healthy assimilation surface can contribute.

Some methods use other special factors, too. For example the Standard Tree Evaluation Method for trees over 50 years old takes into account historic, relict, scientific features (Watson, 2002).

\section{International methods}

There are several ways to place a value on plant material. Armstrong (1947) reviewed various formulas and concluded that they were all arbitrary. Calculations based on different methods can lead to very different results. Therefore good judgment through experience is important in selecting the method to use, for no one method can be used under every condition (King, 1977).

The commonly used appraisal methods are presented in Table 1. One of the simplest formulas (Kielbaso, 1979), based on which other methods were elaborated is:

Value $=$ basic value or replacement cost $\times$ species $\times$ condition $\times$ location.

Table 1. International tree appraisal methods

\begin{tabular}{|c|c|}
\hline Method & Formula \\
\hline $\begin{array}{l}\text { CTLA - Guide for Plant Appraisal } \\
\text { (USA) }\end{array}$ & $\begin{array}{c}\text { trunk area at } 1.4 \mathrm{~m}(4.5 \mathrm{ft}) \times \text { basic price } \times \text { species } \mathrm{x} \text { condition } \times \\
\text { location }\end{array}$ \\
\hline Revised Burnley Method (Australia) & $\begin{array}{c}\text { tree volume } \times \text { base value } \times \text { life expectancy } \times \text { form and vigour } \times \\
\text { location }\end{array}$ \\
\hline $\begin{array}{l}\text { Helliwell - Amenity Valuation of } \\
\text { Trees and Woodlands (Great } \\
\text { Britain) }\end{array}$ & $\begin{array}{l}\text { tree size }(\text { cross-sectional area of the crown }) \times \text { life expectancy } \times \\
\text { importance in the landscape } \times \text { presence of other trees } \times \text { relation } \\
\text { to setting } \times \text { form } \times \text { special factors } \times \text { monetary conversion value } \\
\qquad(£ 25 \text { in } 2008)\end{array}$ \\
\hline $\begin{array}{l}\text { STEM - Standard Tree Evaluation } \\
\text { Method (New Zealand) }\end{array}$ & $\begin{array}{l}\text { [total points of } 20 \text { tree attributes }(540 \text { possible }) \times \text { wholesale cost } \\
+ \text { planting cost }+ \text { maintenance cost }] \times \text { retail conversion factor }(2 \\
\text { suggested })\end{array}$ \\
\hline Norma Granada (Spain) & $\begin{array}{c}(\text { value factor based on species and size } \times \text { wholesale cost } \times \\
\text { condition }) \times[1+\text { life expectancy }+(\text { aesthetic value }+ \text { species } \\
\text { rarity }+ \text { site suitability }+ \text { extraordinary })]\end{array}$ \\
\hline $\begin{array}{l}\text { CAVAT - Capital Asset Value for } \\
\text { Amenity Trees (Great Britain) }\end{array}$ & $\begin{array}{c}\text { basic value based on the trunk area } \times \text { location-accessibility factor } \\
\times \text { functional factor } \times \text { amenity and appropriateness factor } \times \text { safe } \\
\text { life expectancy factor }\end{array}$ \\
\hline Koch (Germany) & $\begin{array}{l}\text { planting cost }+ \text { follow-up care (first } 3 \text { years) + maintenance costs } \\
\text { of the further period }\end{array}$ \\
\hline
\end{tabular}

Some methods are based on the measurement of the cross-sectional area of the trunk

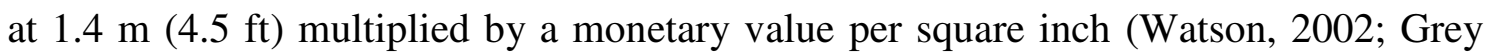
and Deneke, 1986). According to Dreesen (2005) the trunk formula method usually underestimates the value of small trees, but is frequently used in estimating values of trees larger than 8 inches in diameter measured at 4.5 feet above the ground. According to the Guide for Plant Appraisal (USA), this value should be modified by species, condition and location. Dreesen (2005) presents the tables for species grouping, condition classification and location values used in Texas. This method is outstanding in the determination of the condition. There are six condition factors, each rating from one to five. The sum of the rating for each of the six factors is the tree's condition rating. 
The Helliwell method (Helliwell, 2000) is very easy to use. It is based on six standard factors and any special factors such as historical association or exceptional rarity can also be applied where required. Each factor is scored from 1 to 4 points and the scores for all factors are multiplied to give an assessment for a given tree. At the end an assigned monetary value per point can be used.

There are two versions of the CAVAT method. The Full Method is recommended for use in decisions concerning individual trees or groups, when precision is required and sufficient time is available for a full assessment. The Quick Method is intended specifically as a strategic tool for management of the stock as a whole, as if it were a financial asset of the community (Neilan, 2010). The Quick Method involves three steps and key variables:

- Basic value / size

- CTI (Community Tree Index) value

- Functional value.

The basic value is determined by the trunk diameter, according to given categories. For the purposes of CAVAT the exact size is not needed. The basic value of the tree population will be adjusted according to the population density of the urban areas. The functional value can be retained at $100 \%$, but may be reduced according to the crown size or the condition (e.g., need for any immediate works).

Watson (2002) compared five tree appraisal methods (CTLA, Standard Tree Evaluation Method, Helliwell, Norma Granada and Burnley) used in different countries. In his study nine individuals with professional interest in the value of urban trees appraised the same six trees using all five methods. He found that there is not only an essential difference among the resulting values of the methods, but a strong relationship between variation among appraisers and the mathematical operations used in the formulas. Formulas, which multiply all of the rated factors together, consistently produced highest variation among appraisers, while methods which add all the factors together, consistently produced the lowest variation among appraisers.

Sarajevs (2011) compared the CAVAT, Helliwell and i-Tree methods. He also stated that the valuation systems differ significantly in methodology, data requirements and outputs. While the Helliwell method is based on expert judgements, the i-Tree requires data collected from a sample or a complete inventory of the street tree population as well as community-specific information (e.g., programme management costs, city population size, and price of residential electricity), and CAVAT is somewhere in between. CAVAT and i-Tree take substantial account of the social/cultural value component of trees. But Sarajevs (2011) calls the attention that none of the three systems is able to comprehensively quantify the biodiversity or social/cultural benefits of the trees despite these value components often being considered the most important to society.

\section{Hungarian methods}

In Hungary the most commonly used method was developed by Dezső Radó (Radó, 1981), based on multiplication of factor values. The base value in this method is the cost of a standard four-year sapling at a given location in the assessment period. The base value should be modified according to the age, location and condition of the tree. The life-time factor is given by leaf counting up to 70 years of age, above this there is no differentiation. The base value of the location and condition factors is 1 . In case of worse condition of a tree, the value of this factor can be 0.7 or 0.4 . Regarding the 
location, the value of 1 refers to crowded urban areas, in case of smaller towns 0.7 , in villages and rural areas 0.4 should be used.

Less common is the Párkányi method (Jószainé Párkányi, 2007). This calculation is based on the canopy size, taking into account the growth phases of the trees, including species specific growth functions. Therefore, the method is more complicated, but a table, which holds average growth values, simplifies its use. The values of the crown condition factor are the same as in case of Radó method, but the age and location factors are different, the multiplication values are slightly lower in this method.

The advantage of the Radó method is its reputation, most of the professionals can use it. However, a serious problem is the application of the standard four-year sapling as a base value. Over the years, buyers and landscape architectures are becoming more demanding regarding the size of the trees, so the nursery production shifted to the older and larger plants. Thus, the standard four-year sapling (about $8 / 10$ circumference) is not included in most of the nursery offers. The Párkányi method attempts to improve the Radó method. On the one hand the age factor is given up to 190 years, on the other hand two-times replaced sapling with a size of 10/12 circumference is used as base value. Both methods have the obvious advantage that the initial value is determined by the price of a sapling (Table 2), which can be in any currency.

Table 2. Hungarian tree appraisal methods

\begin{tabular}{c|c}
\hline Method & Formula \\
\hline Radó & basic price $\times$ age $\times$ location $\times$ condition \\
Párkányi & basic price $\times$ age $\times$ crown condition $\times$ location \\
\hline
\end{tabular}

\section{Materials and methods}

The tree survey held place in one the greenest districts of Budapest in the summer of 2010, financed by a tender. The last similar district-wide survey was in 1996, in the intermediate time only the major changes were recorded.

The area of the district is $36.34 \mathrm{~km}^{2}$, but the survey was carried out only in the inner city areas of $22.64 \mathrm{~km}^{2}$ size. The survey covered all of the trees in public areas managed by the local government. However, the district has some parts belonging to the management of the capital, where no survey was done (about $5 \%$ of the trees in the district). The survey was based on a parcel-level map of the district, divided in 102 sectors and carried out by measuring pairs by sectors. The exact location of the trees was determined relative to the locations of the properties using measuring tapes and laser distance meters and marked on the map. The attributes of the trees were recorded in previously prepared form sheets. The location, species (in Hungarian and Latin name), age and some properties (height, crown diameter, height and circumference of the trunk) were recorded. Beside the condition of the crown, trunk and roots, the state of protection or endangered and also the lack of management operations were examined. The potential negative effects of the tree (risks for transport, public utilities or accidents) were also assessed.

Each tree got a unique identifier formed from the letter of the measurement group, the sector number and the number of the tree within the sector. A digital photo was taken too, documenting the condition and the surroundings of each tree. At the end of the day the measuring groups uploaded all data and photo through an Internet-based 
system. After completing a sector, the trees marked on the paper maps were digitised by landscape architects using AutoCAD. From there it was possible to calculate the EOV coordinates of the trees.

\section{Results}

\section{Composition of the trees}

During the survey 27450 records were admitted, but there were not so many trees. In 414 cases the name was "stock", when in a small space like in a splay several trees/shrubs live together, but have a dominant species. In 483 cases lack of tree was recorded, that appears to have ever a tree there as a remaining trunk or furrow could be observed, but no living tree can be found. The local government had particular interest in the lack of trees, which may be important for the future re-plantings. There were 4 records called "root", in these cases only some root pieces were left in the place of the trees, it can be considered same as lack of tree. In 57 cases the tree was unrecognisable, the measuring groups could not identify because they were completely dry or had severe disease. Therefore, a total of 26492 separate accurately identified trees were found in the area examined, which form the basic of the further analyses.

According to the database 220 species can be found in the district. In case of 90 species there are less than 10 specimens, in case of 22 species only 1-1 sample can be found in the area, so these species are negligible in maintenance and workorganisational aspects. The most significant species (Table 3) have more than 300 specimens.

Table 3. The most significant species of the district

\begin{tabular}{c|c}
\hline Botanical name & Count \\
\hline Acer platanoides & 2377 \\
Robinia pseudoacacia & 2127 \\
Juglans regia & 1702 \\
Fraxinus excelsior & 1334 \\
Prunus cerasifera & 1218 \\
Prunus domestica & 979 \\
Prunus cerasus & 823 \\
Tilia cordata & 819 \\
Sophora japonica & 794 \\
Betula pendula & 706 \\
Aesculus hippocastanum & 633 \\
Celtis occidentalis & 622 \\
Acer campestre & 603 \\
Fraxinus ornus & 599 \\
Ailanthus altissima & 536 \\
Tilia tomentosa & 443 \\
Acer negundo & 434 \\
Thuja occidentalis & 426 \\
Tilia platyphyllos & 393 \\
Koelreuteria paniculata & 389 \\
Platanus x hybrida & 321 \\
Acer pseudoplatanus & 321 \\
\hline &
\end{tabular}

It is worth examining the ratio of the deciduous and evergreen species as well. There are 177 deciduous species with a total of 24523 specimens, while 43 evergreen species 
with1980 specimens in the district. Evergreens are often of higher demand for environmental factors and are less tolerant to polluted air that can be an explanation for this somewhat distorted ratio. It should be noted, however, that the nursery price of the evergreens is higher than that of deciduous trees, so deciduous trees are more favoured to reduce the planting cost.

According to Simson (2010), trees that have the greatest capacity to improve urban air quality are:

- Acer campestre (603)

- Acer platanoides (2377)

- Alnus glutinosa (8)

- Betula pendula (706)

- Fraxinus excelsior (1334)

- Larix sps. (12)

- some Pinus species.

The numbers in parentheses indicate the numbers of the specimens found in the district examined. As it can be seen, the great number of Acer platanoides and Fraxinus excelsior is favourable. Larix and Alnus species are rarely found in public places in Hungary, there are only few individuals in the study area. Pinus species can be found mainly in mountainous settlements, in Budapest they are rare. In the study area Pinus nigra (141) and P. sylverstris (37) can be found in considerable amount. Theses species are only about $20 \%$ of the total plants, the optimal ratio would be $30-40 \%$.

\section{The age of the trees}

The overall average age of the trees in the district is 19.29 years. Considering the average values (Table 4), even the youngest important species are over ten years.

Table 4. Age of the most significant species

\begin{tabular}{c|c|c}
\hline Botanical name & Average of the age & St. deviation of the age \\
\hline Sophora japonica & 38.58 & 15.74 \\
Aesculus hippocastanum & 31.57 & 15.39 \\
Koelreuteria paniculata & 28.42 & 16.48 \\
Tilia platyphyllos & 27.65 & 14.02 \\
Juglans regia & 26.71 & 11.94 \\
Platanus xybrida & 26.23 & 22.15 \\
Tilia tomentosa & 25.44 & 13.60 \\
Celtis occidentalis & 23.93 & 14.77 \\
Acer negundo & 22.48 & 14.97 \\
Tilia cordata & 22.04 & 14.09 \\
Robinia pseudoacacia & 22.00 & 13.41 \\
Acer campestre & 19.96 & 13.29 \\
Betula pendula & 19.05 & 8.90 \\
Acer pseudoplatanus & 19.03 & 12.42 \\
Ailanthus altissima & 18.48 & 12.10 \\
Prunus cerasus & 18.47 & 8.56 \\
Prunus domestica & 16.66 & 8.08 \\
Fraxinus excelsior & 16.40 & 11.51 \\
Acer platanoides & 15.85 & 9.40 \\
Prunus cerasifera & 15.61 & 8.73 \\
Fraxinus ornus & 15.38 & 8.36 \\
Thuja occidentalis & 10.36 & 5.18 \\
\hline
\end{tabular}


The oldest species are Sophora japonica, Aesculus hippocastanum, Populus $x$ Canadensis and Tilia europea. This is not surprising, since these were the most popular ornamental trees in the past, and were planted almost entirely in certain eras.

\section{Condition}

The crown condition is a critical parameter in the tree evaluation. Table 5 indicate the proportion of the trees with entire crown in case of the most important species.

The bad value of the Robinia pseudoacacia should be highlighted. This is the second most common species in the district, but $40 \%$ of the trees do not have entire, healthy crown. This is problematic both aesthetic reasons and due to the possible risk of accidents. In another survey conducted also in Budapest (VIII. District, Orczy Garden) in the year 2007, Robinia pseudoacacia showed similarly poor results (Hegedüs, 2008). Based on the experiences this species has a high susceptibility for drying, especially in case of older trees there are more dried ones compared to other species.

In case of the species composition it was mentioned now that because of the absence or severe damages 544 trees should be replaced by all means in the area examined.

Table 5. Proportion of the trees with entire crown

\begin{tabular}{c|c}
\hline Botanical name & Entire crown \\
\hline Thuja occidentalis & $88 \%$ \\
Betula pendula & $83 \%$ \\
Acer pseudoplatanus & $79 \%$ \\
Prunus cerasifera & $79 \%$ \\
Fraxinus excelsior & $78 \%$ \\
Fraxinus ornus & $76 \%$ \\
Aesculus hippocastanum & $75 \%$ \\
Ailanthus altissima & $75 \%$ \\
Juglans regia & $74 \%$ \\
Platanus x hybrida & $74 \%$ \\
Acer platanoides & $73 \%$ \\
Acer campestre & $72 \%$ \\
Tilia cordata & $72 \%$ \\
Tilia tomentosa & $72 \%$ \\
Celtis occidentalis & $67 \%$ \\
Tilia platyphyllos & $67 \%$ \\
Prunus domestica & $66 \%$ \\
Acer negundo & $62 \%$ \\
Robinia pseudoacacia & $60 \%$ \\
Koelreuteria paniculata & $58 \%$ \\
Prunus cerasus & $53 \%$ \\
Sophora japonica & $53 \%$ \\
\hline
\end{tabular}

\section{Proportion of the fruit trees and ornamental trees}

In case of street trees the number of the fruit trees needs a special attention. The formulas for tree evaluation usually cannot determine the value of fruit or nut bearing trees, which can be appropriately determined by crop yield.

In the previous decades it was usual in Hungary planting fruit trees along the streets, but due to the resulting problems nowadays they are not planted. The most important problem of the fruit trees is caused by the falling fruits, requiring continuous cleaning in the ripening season to avoid slipping and accidents. The falling fruits are attractive for 
various insects and especially wasps are problematic because of their dangerous sting. Interesting question could be also the proliferation of the pests, as in public areas the plant protection is unusual. These pests can easily infect the trees in home gardens, and despite the treatments carried out in the gardens, that trees can get an infection again from the public places.

A total of 4366 fruit trees have been recorded in the district. 315 belong to the nuts (e.g., Castanea sativa, Coryllus colurna, Jugland regia), which cause less pollution, so the fruit trees should be evaluated without this specimens. However, the remaining 4051 fruit trees require special attention. The district has a garden suburb region, fruit trees are dominant there.

It is worth to examine the ownership status of these trees. Trees in public areas belong to the local government, therefore planting, cutting or trimming requires permission. However, many people planted fruit trees in front of their houses, which they consider their own property. Since the life cycle of the fruit trees is usually shorter than that of the ornamental trees, cutting and replacement is more frequent. Few people applies for the required permission, therefore penalty occurs often.

\section{Monetary value of the trees}

In the review of literature it was mentioned now, that calculations based on different methods can lead to very different results. In this study only some calculations were done as an example. In Table 6 monetary values of three different species can be seen. The condition of the trees was considered good in all cases and the location was also assumed to be the same (appropriate to the value 1 in the Radó method), while the age of the trees was different to present its effect.

Table 6. Tree values calculated with different methods (in HUF)

\begin{tabular}{c|c|c|c}
\hline Method & $\begin{array}{c}\text { Acer platanoides } \\
\text { 20 years }\end{array}$ & $\begin{array}{c}\text { Celtis occidentalis } \\
\text { 40 years }\end{array}$ & $\begin{array}{c}\text { Fraxinus excelsior } \\
\text { 20 years }\end{array}$ \\
\hline Radó method & 180000 & 800000 & 120000 \\
Párkányi method & 360750 & 2047500 & 277500 \\
Revised Burnley Method & 558795 & 5747607 & 347695 \\
CAVAT quick method & 716380 & 4815080 & 1203940 \\
CTLA (Texas) & 274873 & 2681042 & 1932700 \\
Helliwell & 380800 & 1713600 & 380800 \\
\hline
\end{tabular}

The very different results of the methods can be observed, but we can find some explanations for them.

The age of Celtis occidentalis was considered more than that of the other two trees. It is reflected in the results, as its monetary value is much higher in every calculation.

Comparing the Hungarian methods, Párkányi method is based on greater sapling size (10/12 circumference, while $8 / 10$ is in case of Radó), so the basic prices are higher with about $2000 \mathrm{HUF}$. The multiplication values regarding the condition are the same, however there are differences concerning the location and the age. These values are higher in the Párkányi method.

The Helliwell method does not take into account the species, therefore the resulting values of two very different species can be the same. 
The CTLA method has a grouping system for species. Based on the table used in Texas, Fraxinus excelsior has higher species value than Acer platanoides, this is the reason of the different values in case of two trees with similar parameters and location.

Revised Burnley method uses a specific approach, as the base value is the cost per cubic meter of retail nursery stock. This is a problematic part in the calculation, as Hungarian nurseries have other price formation system, therefore the suggested 77 USD was used. In this method tree size is measured as volume of the tree approximated by an inverted cone. In this respect Celtis occidentalis is much greater than the other two species, so the price should be multiple.

Calculation of the replacement cost is also among the used methods, which can be problematic in case of old trees. Let it compare the value of a 15 years old tree, planted as a four-year sapling and the price of a 15 years old tree, which can be bought in a nursery. An Aesculus carnea 'Briotii' in that age and with $35 \mathrm{~cm}$ circumference is 450 Euro in an Italian nursery price list - Hungarian nurseries does not offer such specimens - and the costs of shipping and planting must be added, too. However, the value of a 15 years old tree would be 167 Euro based on Radó method, and 236 Euro according to Párkányi.

\section{Discussion}

There are a number of factors that need to be considered in case of determination of urban tree values. Most of the methods use as a base value the producer price of the nurseries. However, in many cases this could be a wrong solution, as the nursery price depends first of all on the production cost of the given sapling and in small part on the market demand. Therefore, it can occur that a tree with higher production cost but not so valuable in the given conditions would have higher calculated value than another, most suitable one. It can also happen that some varieties of a given species can be propagated only with grafting, others without it. As grafting needs more manpower, these saplings are more expensive. For example, a variety with a globe crown will have higher price than a variety with conventional crown form of the same species, even if the conventional one shows better result in growing vigour and canopy size. Of course the nursery price cannot be avoided during the calculations, but could have less importance.

The value of the trees in crowded and polluted urban areas is higher than in a small settlement. The Hungarian methods do not take it into account with proper extent. Instead of the currently used three categories five location types are suggested:

- inner districts of the capital

- green areas of the capital

- main great cities of the country

- suburban regions

- villages and small settlements.

The species are tolerant to the urban environment in different extent. This value should be determined based on several factors, like tolerance to the dry and warm periods, salinity, pests and diseases. The climate tolerance becomes important in the last years. It is especially important in case of trees, where the change of varieties is slow and they are planted for long time. As the climate scenarios based on different models give different results, exact values cannot be given for this. However, species could be grouped in three categories based on the experiences of the last decades. 
The maintenance cost is also important factor. All the trees have some basic maintenance needs, but species are very different in this aspect. Some species require much more maintenance work, for example continuous cleaning because of the falling crops (Aesculus hippocastanum) or falling flowers (Tilia sp.), or because of the high risk of broken branches (Gleditsia triacanthos). The extra costs slightly decrease the value of these trees.

The re-evaluation of the trees after the maintenance works is an interesting question. There are cases, when the professional maintenance works (e.g., removal of dry branches, plant protection) increase the tree value. It calls the attention again to the continuous update of the tree cadastral databases. All manipulations must be recorded immediately and tree values must be re-calculated.

Acknowledgements. The authors would like to express their gratitude for the "Green Budapest" scholarship of the Viva Natura Foundation providing support for the study.

\section{REFERENCES}

[1] Armstrong, N. (1947): Shade tree evaluation formulas and their use. - Proceedings of the 23rd International Shade Tree Conference, p. 38-48.

[2] Bulîr, P. (2009): Testing of Koch method applied for evaluation of ornamental trees in the Czech Republic. - Hort. Sci. (Prague), 36(4): 154-161.

[3] Cullen, S. (2007): Putting a value on trees - CTLA guidance and methods. Arboricultural Journal 30: 21-43.

[4] Dreesen, A.D. (2005): Evaluation of Texas shade trees. - Texas Cooperative Extension, http://www.plantanswers.com/EvaluationOfTexasShadeTrees.pdf

[5] Grey, G.W., Deneke, F.J. (1986): Urban Forestry. - John Wily and Sons, New York.

[6] Hegedüs, A. (2008): Az Orczy-kert dendrológiai felmérése. - Kertgazdaság 40(2): 58-62.

[7] Helliwell, D.R. (2000): Amenity valuation of trees and woodlands (rev. ed.). Arboricultural Association, Romsey, Hants, United Kingdom.

[8] Jószainé Párkányi, I. (2004): Értékbecslési módszerek. - In: Schmidt G., Varga G. (szerk.): Famutató. Fásítási útmutató tervezéshez, kivitelezéshez és fenntartáshoz. Hillebrand Nyomda, Sopron

[9] Jószainé Párkányi, I. (2007): Zöldfelület-gazdálkodás, parkfenntartás. - Mezőgazdasági Kiadó, Budapest

[10] Kielbaso, J. (1979): Evaluation of trees in urban areas. - Journal of Arboriculture 5(3): 70-72.

[11] King, G.S. (1977): Plant material evaluation. - Journal of Arboriculture 3(4): 61-64.

[12] Kissinger, D., Van Ells, J. (1998): Tree Evaluation and appraisal. - Wisconsin Urban \& Community Forests 6(3): 1 and 9-11.

[13] Litchfield, G. (2010): A simple tree evaluation system. - Latvijas Kokkopju-Arboristu Biedriba Seminar, $27^{\text {th }}$ May 2010, Riga

http://www.kokiem.lv/seminars-koks-ka-patiesa-vertiba/6_De_G_Litchfield_tree_valuation.pdf

[14] Moor, G.M. (1991): Amenity tree evaluation: A revised method. - In: The Scientific Management of Plants in the Urban Environment. Proceedings of the Burnley Centenary Conference, Centre for Urban Horticulture, Melbourne, Australia., p. 166-171. http://www.arborcad.com/wp-content/uploads/2011/08/Arborcad-Revised-Burnley-Method-ofTree-Valuation.pdf 
[15] Neilan, C. (2010): CAVAT, Quick Method: User's Guide. - London Tree Officers Association,

http://www.ltoa.org.uk/documents/resource-home/doc_download/140-cavat-quickmethod-user-guide-updated-september-2010

[16] Radó, D. (1981): Fák a betonrengetegben. - Mezőgazdasági Kiadó, Budapest

[17] Sarajevs, V. (2011): Street tree valuation systems. - Forest Research, April 2011, p. 1-6. http://www.forestry.gov.uk/pdf/FCRN008.pdf/\$FILE/FCRN008.pdf

[18] Simson, A. (2010): The value of trees http://www.historictownsforum.org/files/documents/presentations/Oxford_10/Alan_Simson.pdf

[19] Watson, G. (2002): Comparing formula methods of tree appraisal. - Journal of Arboriculture 28(1): 11-18. 